\begin{tabular}{|c|c|c|c|}
\hline $\begin{array}{c}\text { RESEARCH } \\
\text { ARTICLE } \\
\end{array}$ & $\begin{array}{r}\text { ADVANCE RESEAR } \\
\text { Volume } 9 \mid \text { Iss }\end{array}$ & CIAL SCIENCE & \\
\hline $0=$ & DOI: 10.15740/HAS/ARJSS/9.1/7-13 & Visit us : www.researchjournal.co.in & \\
\hline
\end{tabular}

\title{
Affect of child related factors on family relation of mentally challenged children
}

Manjula Patil* and Arogyaasha A. Shali

Department of Human Development and Family Studies, College of Community Science, University of Agricultural Sciences, Dharwad (Karnataka) India

(E-mail : blmmanju@yahoo.co.in; arogyaashashali92@gmail.com)

\section{ARTICLE INFO :}

$\begin{array}{lll}\text { Received } & : & 24.11 .2017 \\ \text { Revised } & : & 16.04 .2018 \\ \text { Accepted } & : & 02.05 .2018\end{array}$

KEY WORDS :

Family relation, Mentally challenged, Child factors

HOW TO CITE THIS ARTICLE :

Patil, Manjula and Shali, Arogyaasha A. (2018). Affect of child related factors on family relation of mentally challenged children. Adv. Res. J. Soc. Sci., 9 (1) : 713, DOI: 10.15740/HAS/ARJSS/9.1/713.

Copyright@2018 : Hind Agri -

Horticultural Society

*Author for correspondence

\begin{abstract}
The families of children with intellectual disabilities are different from person to person and family to family. The present study examined a total of 45 parents of children with intellectual disabilities fifteen villages of nine taluks of five districts of northern Karnataka as rural samples and 32 mentally challenged children enrolled from the four special schools of Hubli and Dharwad city as urban samples for the study and taken child related factors such as locality, age, gender and ordinal position of the child. Family relationship inventory (FRI): Brunken and Crites 1964 were used for the study. Results indicated that there is association between locality and the family relationship of mentally challenged children. Rural children had high family relations (33.8\%) compared to urban children. When the gender is compared with the family relationship highest percentage of girls was found in medium level of family relationship. 5-12 age group children were having high family relationship as compared with the 13-18 year age group children. When order of birth is taken first born children among them high level of family relationship. Family intervention programmes need to be focused on early building and strengthening the natural support systems for the parents.
\end{abstract}

